Article

\title{
Increasing the Biogas Potential of Rapeseed Straw Using Pulsed Electric Field Pre-Treatment
}

\author{
Dawid Szwarc $1, *$ (D) and Katarzyna Głowacka ${ }^{2}$ (D) \\ 1 Department of Environmental Engineering, Faculty of Geoengineering, University of Warmia and Mazury \\ in Olsztyn, 10-720 Olsztyn, Poland \\ 2 Department of Plant Physiology, Genetics and Biotechnology, University of Warmia and Mazury in Olsztyn, \\ 10-720 Olsztyn, Poland; katarzyna.glowacka@uwm.edu.pl \\ * Correspondence: dawid.szwarc@uwm.edu.pl
}

Citation: Szwarc, D.; Głowacka, K. Increasing the Biogas Potential of Rapeseed Straw Using Pulsed Electric Field Pre-Treatment. Energies 2021, 14, 8307. https://doi.org/10.3390/ en14248307

Academic Editor: Byong-Hun Jeon

Received: 14 October 2021

Accepted: 7 December 2021

Published: 9 December 2021

Publisher's Note: MDPI stays neutral with regard to jurisdictional claims in published maps and institutional affiliations.

Copyright: (c) 2021 by the authors. Licensee MDPI, Basel, Switzerland. This article is an open access article distributed under the terms and conditions of the Creative Commons Attribution (CC BY) license (https:// creativecommons.org/licenses/by/ $4.0 /)$.

\begin{abstract}
Due to the high availability of lignocellulosic biomass, which can be obtained from terrestrial plants, agricultural waste biomass, and the agro-food, paper or wood industries, its use for energy production by methane fermentation is economically and environmentally justified. However, due to their complex structures, lignocellulosic substrates have a low conversion factor to biogas. Therefore, scientists are still working on the development of new methods of the pre-treatment of lignocellulosic materials that will increase the biogas productivity from lignocellulosic biomass. The presented research focuses on the use of a pulsed electric field (PEF) to disintegrate rapeseed straw prior to the methane fermentation process. Scanning electron microscopy observation showed that, in the disintegrated sample, the extent of damage to the plant tissue was more severe than in the control sample. In the sample disintegrated for $7 \mathrm{~min}$, the chemical oxygen demand increased from $4146 \pm 75 \mathrm{mg} / \mathrm{L}$ to $4920 \pm 60 \mathrm{mg} / \mathrm{L}$. The best result was achieved with a 5-min PEF pre-treatment. The methane production reached $290.8 \pm 12.1 \mathrm{NmL} \mathrm{CH}_{4} / \mathrm{g} \mathrm{VS}$, and the biogas production was $478.0 \pm 27.5 \mathrm{NmL} / \mathrm{g}$ VS; it was $14 \%$ and $15 \%$ higher, respectively, compared to the control sample.
\end{abstract}

Keywords: pulsed electric field; anaerobic digestion; methane fermentation; biogas production; lignocellulose; rapeseed straw

\section{Introduction}

The world's primary energy consumption is $88 \%$ covered by fossil fuels [1], which is unfortunately associated with the release of greenhouse gases into the atmosphere as a result of their combustion [2]. Due to the negative environmental impact of the use of fossil fuels, replacing them with renewable energy offers an opportunity to reduce the global greenhouse effect [3]. The application of technologies for the conversion of biomass into energy carriers such as biogas production [4], biodiesel production [5], hydrogen production [6], ethanol production [7,8], pyrolysis [9] and hydrothermal liquefaction [10] is seen as a sustainable technology for meeting energy demand, reducing greenhouse gas emissions as well as reducing the amount of waste entering the environment [11-13]. Therefore, the development of biogas technologies should be based on the use of agricultural wastes and residues [14]. One way to reduce the use of fossil fuels is to replace them with a clean energy carrier such as biogas, which can be used to generate heat and electricity, and can be used to power combustion engines [15]. In terms of environmental and social sustainability, lignocellulosic biomass has great potential for biogas production [14]. Lignocellulosic biomass resources, which consist of both terrestrial plants and waste biomass from the agriculture, agro-food, paper and wood industries, are the largest biomass resources available in the world [16]. The use of lignocellulosic biomass, due to its wide availability and high sugar content, can make a large contribution to meeting the world's energy demand [17,18]. Rapeseed is an important oil plant in the world, grown for the production of vegetable oil, which is used mainly for the production of cooking oil or biofuels. In many countries, rape 
straw is a large source of biomass. China's rapeseed straw production in 2014 exceeded 16 billion tonnes. It is usually used as a low-value feed additive, mulch or fertilizer $[19,20]$. Rapeseed straw consists of cellulose, hemicellulose and lignin, and due to the content of fermentable sugars, it can be converted into biofuels [21,22].

Lignocellulosic biomass consists mainly of $30-50 \%$ cellulose, $15-35 \%$ hemicellulose and $10-20 \%$ lignin, which form a heterogeneous complex characterized by a high degree of resistance to enzymatic hydrolysis [23-28]. The structure of lignocellulosic biomass means that it is underutilized and has a low conversion rate to biogas. The solution to this problem may be the use of pre-treatments aimed at the damage of the hydrogen bonds of hemicellulose and lignin. The pre-treatment of the substrate is intended to reduce the crystallinity and the degree of polymerization of the cellulose. The use of treatment processes should loosen the structure of the biomass, which will increase the availability for microorganisms. Effective pre-treatment should provide the separation of lignin from cellulose, a high amorphous cellulose content, high substrate porosity, no sugar loss, reduced inhibitor production and low energy input [29]. The commonly used conditioning techniques can be divided into physical, physicochemical, chemical and biological techniques [30-34] (Figure 1).

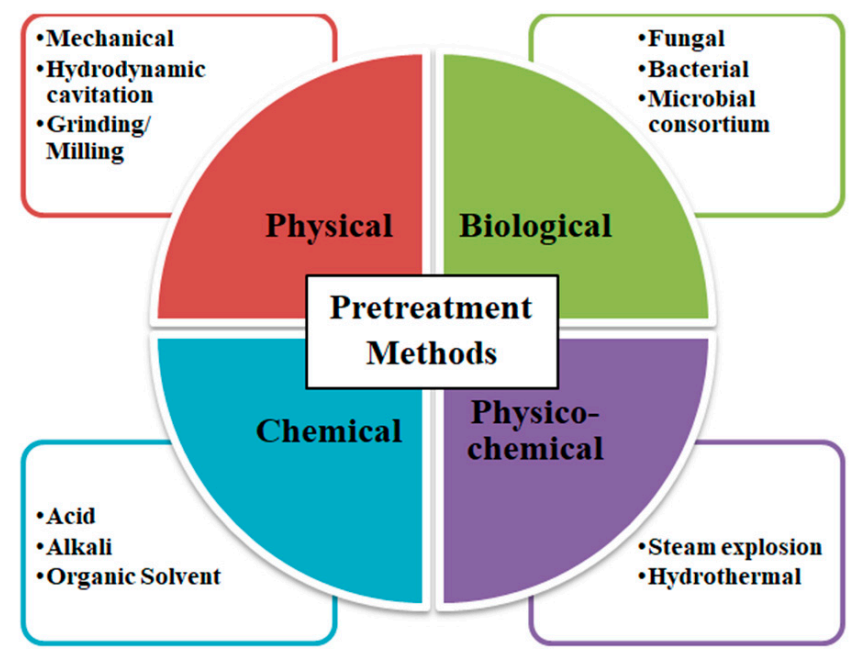

Figure 1. Methods of the pretreatment of lignocellulosic biomass.

The use of pulsed electric field (PEF) technology in biogas production has not been frequently studied to date. Previous literature reports indicate that PEF pre-treatment has mainly been applied to liquid and semi-liquid substrates, i.e., sludge and wastewater. The effect of PEF on the disintegration of lignocellulosic substrates in methane fermentation has not yet been sufficiently explored. Nevertheless, scientific studies suggest that PEF pre-treatment may increase the permeability of cell membranes, resulting in the increased release of solutes [35,36]. Moreover, previous studies indicate that the application of a PEF to pre-treatment prior to anaerobic digestion reduces retention times by increasing reaction rates [37].

The mechanism of action of PEF involves the application of an external electric field leading to an increase in cell membrane permeability, and is known as electroporation or electropermeabilisation. The effect of PEF on a biological cell depends on the generated electric field intensity, and can lead to reversible changes (the sealing of pores) or irreversible changes (the death of a biological cell) (Figure 2) [37].

The current study aimed to determine the biogas potential of rapeseed straw pretreated with PEF. 


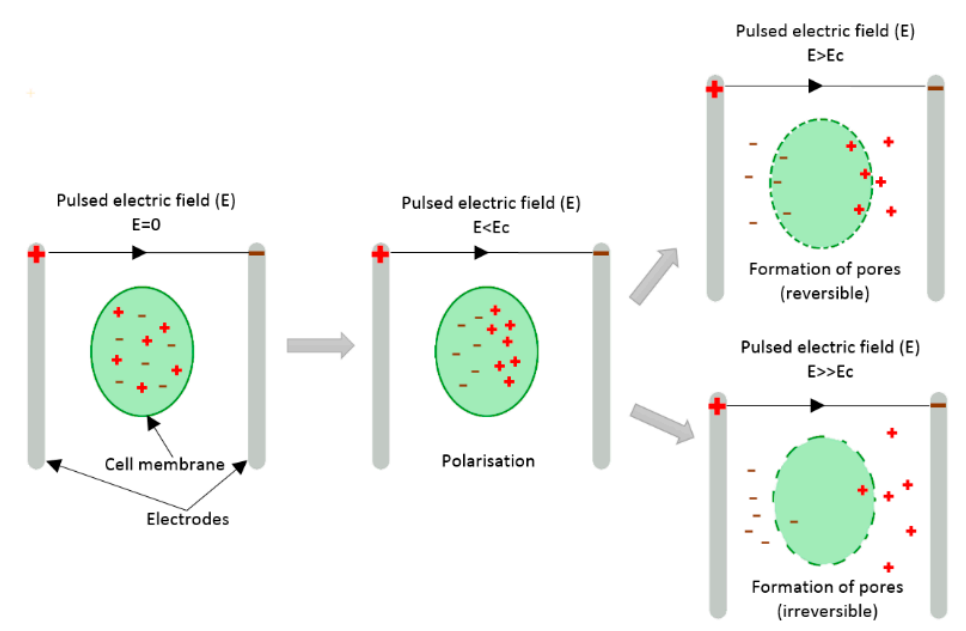

Figure 2. A biological cell exposed to an external electric field (polarization).

\section{Materials and Methods}

\subsection{Substrate}

The substrate used in the methane fermentation process was rapeseed straw. The shredded substrate was hydrated to $95 \%$ with distilled water. The dry matter content (TS) of the test substrate was $92.08 \%$. The organic dry matter (VS) content of the feedstock used was $92.15 \%$ TS (Table 1 ).

Table 1. Characteristics of the rapeseed straw.

\begin{tabular}{cc}
\hline Parameters & Value \\
\hline Hydration [\%] & 7.92 \\
Dry weight [\%] & 92.08 \\
Organic dry matter [\% TS] & 92.15 \\
Total carbon (TC) [mg C/g TS] & 446.32 \\
Total organic carbon (TOC) [mg C/g TS] & 369.43 \\
Total nitrogen (TN) [mg N/g TS] & 18.59 \\
C/N & 24.01 \\
\hline
\end{tabular}

\subsection{Equipment}

The PEF disintegration line consisted of a substrate preparation station equipped with a HAL-50 milling shredder (Börger, Germany) and a substrate tank used for substrate hydration to the required level, while a paddle agitator provided substrate homogeneity throughout the volume. The installation included a pump system enabling the disintegrator to work under flow conditions. Additionally, the installation had a hopper, which allowed it to work in static conditions (Figure 3). The device uses a coaxial disintegration chamber with a capacity of $500 \mathrm{~mL}$. The distance between the stainless steel electrodes was about $2 \mathrm{~cm}$. PEF was generated by applying high voltage electrical pulses to the electrodes. The PEF disintegration line had a high voltage source of $40 \mathrm{kV}$. The use of the disintegrator parameter driver allowed for the setting of the disintegrator operating parameters from the computer.

\subsection{Pretreatment}

The preparation of the raw material for pre-treatment involved grinding the material in a shredder included in the PEF disintegration installation. The shredded rapeseed straw was then hydrated to $95 \%$ by mixing it with distilled water. The substrate prepared in this way was poured through a hopper into the disintegration chamber and then exposed to the PEF. The amplitude of the applied electric pulses was $40 \mathrm{kV}$. A rectangular pulse shape was used. The pulse width was $50 \mu$ s with a pulse repetition frequency of $5 \mathrm{kHz}$. Due to the disintegration chamber's coaxial structure, the electric field was unevenly distributed 
in it. The maximum and minimum electric fields in the disintegration chamber were $38.61 \mathrm{kV} / \mathrm{cm}$ and $11.66 \mathrm{kV} / \mathrm{cm}$, respectively. The lignocellulosic substrate was pre-treated with different treatment times in the disintegration chamber: $0,1,2,3,4,5,6,7,8 \mathrm{~min}$.
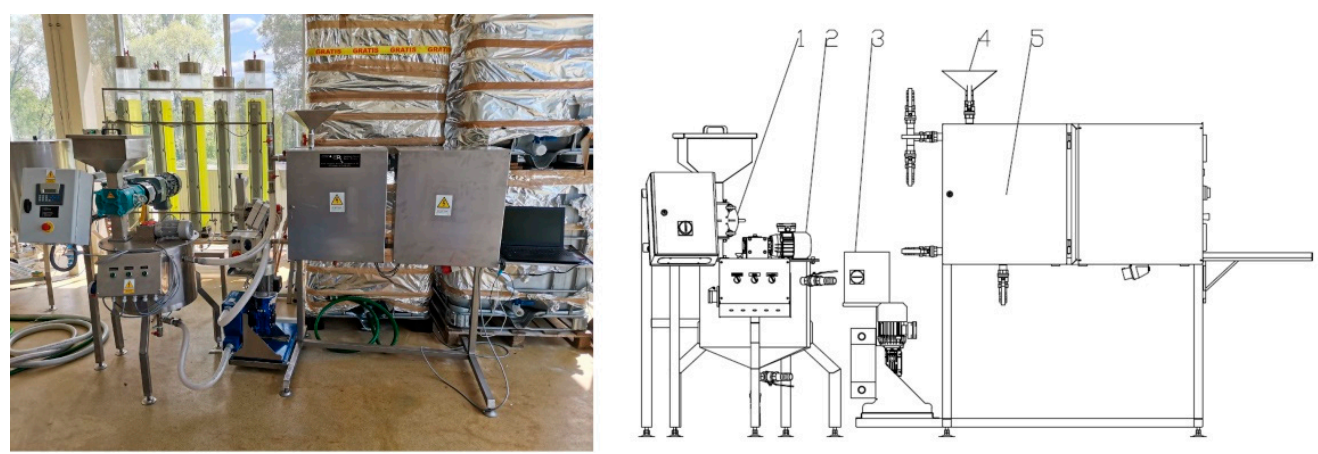

Figure 3. PEF disintegrator: (1) substrate shredder, (2) substrate tank with an agitator, (3) substrate pump, (4) charging hopper, and (5) disintegration chamber cabinet.

\subsection{Determination of the Cellulose, Hemicellulose, and Lignin}

The cellulose, hemicellulose and lignin contents in the material before and after PEF pre-treatment were determined using the method developed by van Soest et al. [38]. The determination consisted of chemical fractionation using neutral and acid detergents, resulting in the determination of neutral-detergent fibre (NDF), acid-detergent fibre (ADF) and acid-detergent lignin (ADL) contents.

The cellulose content was determined according to the following equation:

$$
\text { Cellulose }=\mathrm{ADF}-\mathrm{ADL}
$$

The hemicellulose content was determined according to the following equation:

$$
\text { Hemicellulose }=\text { NDF }- \text { ADF }
$$

The lignin content was determined according to the following equation:

$$
\text { Lignin }=\mathrm{ADL}
$$

\subsection{Analytical Methods}

The raw substrate was centrifuged, and then the content of total organic carbon (TOC) and chemical oxygen demand (COD) in the supernatant was determined. Measurements of the content of neutral detergent fibers (NDF), acidic detergent fibers (ADF) and acidic detergent lignin (ADL) were performed. The same analyses were performed in the supernatant obtained from the samples following disintegration with PEF. In order to determine the biogas potential, methane fermentation was carried out. An AMPTS II analyzer was used for this process. The fermentation process was carried out in $500 \mathrm{~mL}$ reactors equipped with a stirring system. The reactors were mixed every $10 \mathrm{~min}$ for $30 \mathrm{~s}$ at $100 \mathrm{rpm}$. The reactors contained $200 \mathrm{~mL}$ anaerobic inoculum (I) and substrate (S). The ratio of organic matter in the sludge to organic matter in the substrate in the inoculated reactor was I/S $=5$. In order to eliminate oxygen, the reactors were flushed with pure nitrogen. The TS content of the inoculum was $5.91 \pm 0.24 \mathrm{~g} / \mathrm{g}$. The VS content of the inoculum was $4.34 \pm 0.15 \mathrm{~g} / \mathrm{g}$. A negative control sample with an undisintegrated substrate was taken in the study. The methane fermentation was conducted under mesophilic conditions at $37^{\circ} \mathrm{C}$ for 24 days. The experiment was performed in three replicates. In addition, scanning electron microscope (SEM) images were taken of the substrate fragments before and after pre-treatment for the retention time providing the best biogas yield. The samples were dehydrated and then subjected to critical point $\mathrm{CO}_{2}$ drying (BALTEC CPD 030, Leica, Wetzlar, Germany). The dried samples were gold coated in an argon atmosphere using an ion coater (Fine Coater, 
JCF-1200, JEOL, Akishima, Japan). The samples were imaged using an SEM (JSM-5310LV, JEOL, Akishima, Japan) at $15 \mathrm{kV}$ [39].

The analysis of the biogas composition was performed in a gas chromatograph with a thermal conductivity detector (Agilent 7890 A, Santa Clara, CA, USA). The analysis of the TS and VS content was performed using the gravimetric method. The carbon and nitrogen contents in the substrate were measured on a Flash 2000 (Thermo Fisher Scientific, Waltham, MA, USA). The concentration of TOC was measured on the TOC-L instrument (Shimadzu, Kioto, Japan). The detergent fiber fraction content was determined with ANKOM220 (ANKOM Technology, Macedon, NY, USA).

Levene's test was used to determine the homogeneity of variance. Tukey's test (HSD) was used to determine the significance of the differences between the variants. Pearson's correlation $(\mathrm{R})$ was used to determine the correlation between groups of results. The level of significance was $\alpha=0.05$. Statistica 13 (TIBCO, Palo Alto, Santa Clara, CA, USA) software was used for the statistical analyses.

\subsection{Kinetic Evaluations}

Assuming that methane fermentation follows first-order kinetics, the production of methane can be described by the following equation:

$$
C=C_{e} \times\left(1-e^{k \cdot t}\right)
$$

where $\mathrm{C}\left(\mathrm{NmL} / \mathrm{g}\right.$ VS) is the cumulative biogas yield at digestion time $\mathrm{t}, \mathrm{C}_{\mathrm{e}}(\mathrm{NmL} / \mathrm{g}$ VS) is the maximal biogas yield, and $\mathrm{k}(1 / \mathrm{d})$ is the kinetic coefficient of biogas production

The values of $C, C_{e}$ and $k$ were estimated by nonlinear regression using Statistica 13 software (TIBCO).

\section{Results and Discussion}

\subsection{Pretreatment Efficiency}

The initial TOC content was $1499 \pm 38 \mathrm{mg} / \mathrm{L}$. The highest TOC concentration was observed in the sample pre-treated with PEF for $6 \mathrm{~min}$, in which it averaged $1735 \pm 74 \mathrm{mg} / \mathrm{L}$ (Figure 4a). Disintegration with longer retention times did not result in increased TOC contents in the liquid phase of the substrate. For the substrate which was not subjected to PEF disintegration, the chemical oxygen demand averaged $4146 \pm 75 \mathrm{mg} / \mathrm{L}$. The highest COD increase was achieved in the series where the substrate was pre-treated with PEF for $7 \mathrm{~min}$ and reached an average of $4920 \pm 60 \mathrm{mg} / \mathrm{L}$ (Figure 4b). Kuşçu et al. [40] tested the effect of PEF treatment on waste activated sludge (WAS) depending on the applied voltage. The chemical oxygen demand of the raw activated sludge was $245 \mathrm{mg} / \mathrm{L}$. PEF pre-treatment with applied voltages of $12,18,24,30$ and $36 \mathrm{kV}$ increased the dissolved COD to levels of 280, 293, 308 and $405 \mathrm{mg} / \mathrm{L}$. PEF disintegration with the highest voltage of $36 \mathrm{kV}$ increased the dissolved COD by about $65 \%$. Similar observations were made by Deng et al. [41], in which the application of the PEF pre-treatment of activated sludge using an electric field strength of $30 \mathrm{kV} / \mathrm{cm}$ increased the COD by $28.7 \%$.

The effect of using PEF disintegration on the substrate was also determined by analysing the neutral-detergent (NDF), acid-detergent (ADF) and acid-detergent lignin (ADL) fibre fractions. Knowing the content of each fibre fraction allows the determination of the content of cellulose, hemicellulose and lignin in the substrate. The cellulose content of the liquid fraction of the undisintegrated substrate was $49.9 \pm 0.6 \% \mathrm{TS}$, on average. The hemicellulose content was $12.1 \pm 1.2 \% \mathrm{TS}$, and the lignin content was $10.3 \pm 0.5 \% \mathrm{TS}$. The analysis of NDF, ADF and ADL in the PEF pre-treated substrate showed that the best effect was achieved with a retention time of $7 \mathrm{~min}$. The cellulose content decreased to an average of $44.5 \pm 1.1 \%$ TS. The hemicellulose content decreased to an average of $10.3 \pm 0.3 \%$ TS and the lignin content decreased to $9.3 \pm 1.0 \%$ TS (Figure 5). The effect of PEF pre-treatment on the fibre fraction contents was also studied by El Achkar et al. [42]. They used grape pomace as the substrate, and they found no change in the contents of cellulose, hemicellulose or lignin between the raw and disintegrated substrate. 


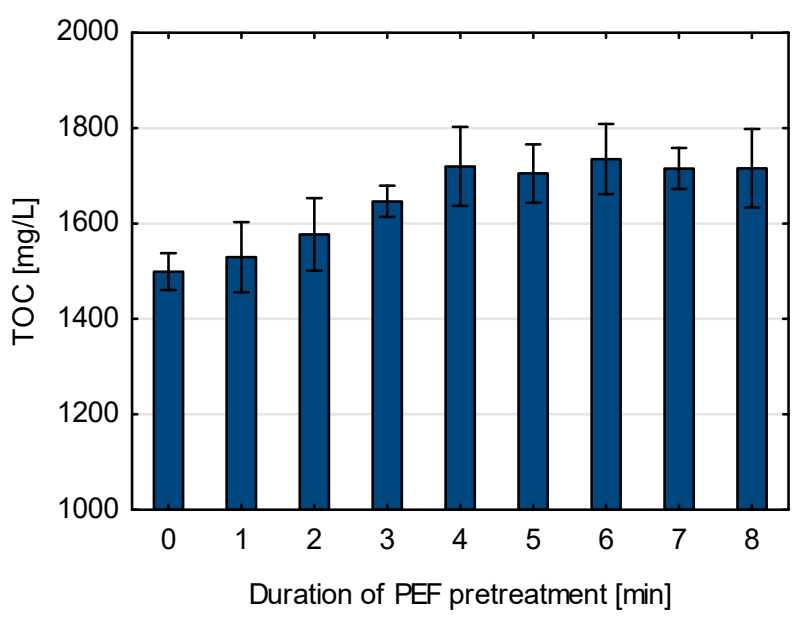

(a)

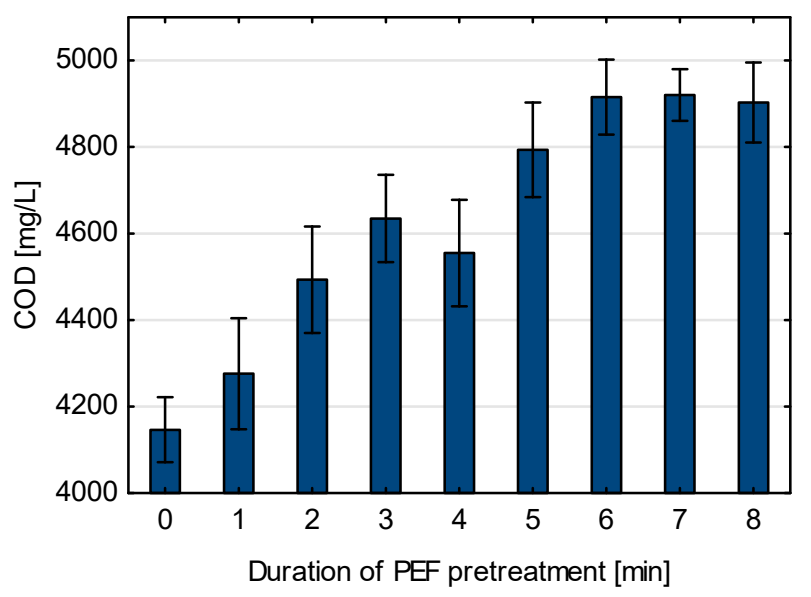

(b)

Figure 4. TOC concentration (a) and COD value (b) in the substrate liquid fraction after PEF disintegration.

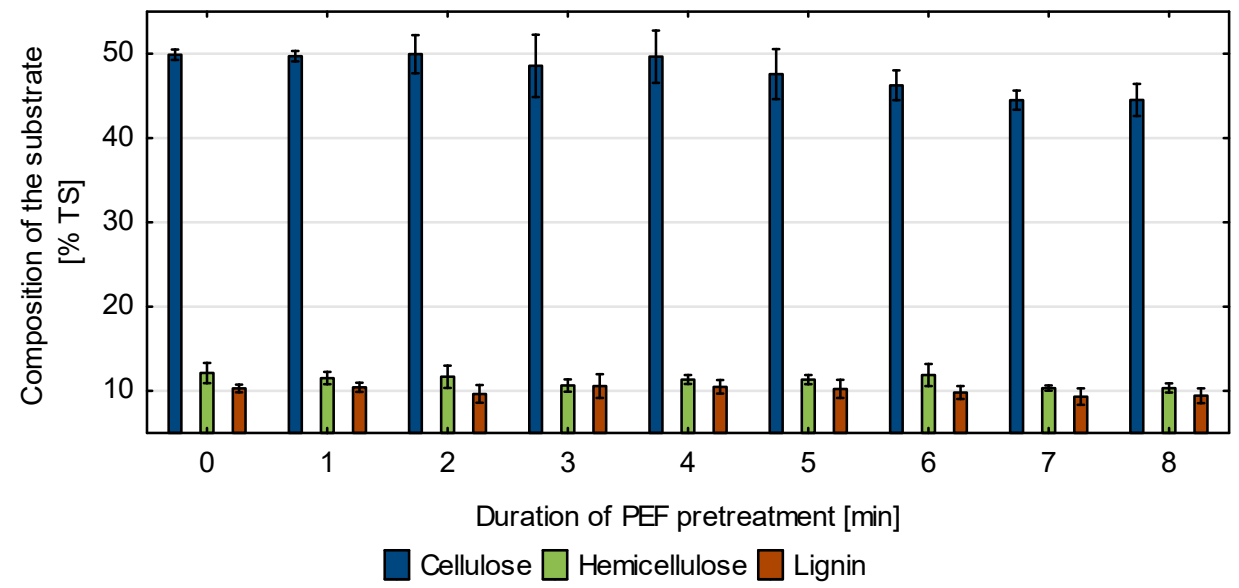

Figure 5. Cellulose, hemicellulose and lignin contents of the PEF-disintegrated substrate.

The microscopic (SEM) observation of the samples showed clear differences between the undisintegrated sample and the sample disintegrated for $5 \mathrm{~min}$.

The destruction of the surface of the control sample and the disintegrated sample was observed (A, B-arrows). However, the extent of the plant tissue damage was more severe in the disintegrated sample $(\mathrm{A}, \mathrm{B})$. In addition, fungal hyphae were observed on the surface of the control and the disintegrated sample (C, D—dotted arrows) (Figure 6). The presence of fungal hyphae on the surface of rapeseed straw is natural, and results from the infection of the crop with fungal diseases. Kim et al. [43] investigated the effect of pre-treatment with PEF on ginseng root, and also noted cell membrane damage under electron microscopy. Kovačić et al. observed structural changes in the lignocellulosic substrate pretreated with electroporation. They showed that the structure of the lignocellulosic substrate was disturbed by pre-treatment. They observed that electroporation led to damage to the cell membrane and the formation of pores [28]. Liu et al. performed an analysis using SEM of the effect of PEF on tea leaf. In their research, they observed unevenly distributed pores on the cell surface that were not present in the untreated PEF sample. In addition to the formation of pores, they also observed highly corrugated, numerous protrusions on the surface of the tea leaf tissues [44]. 

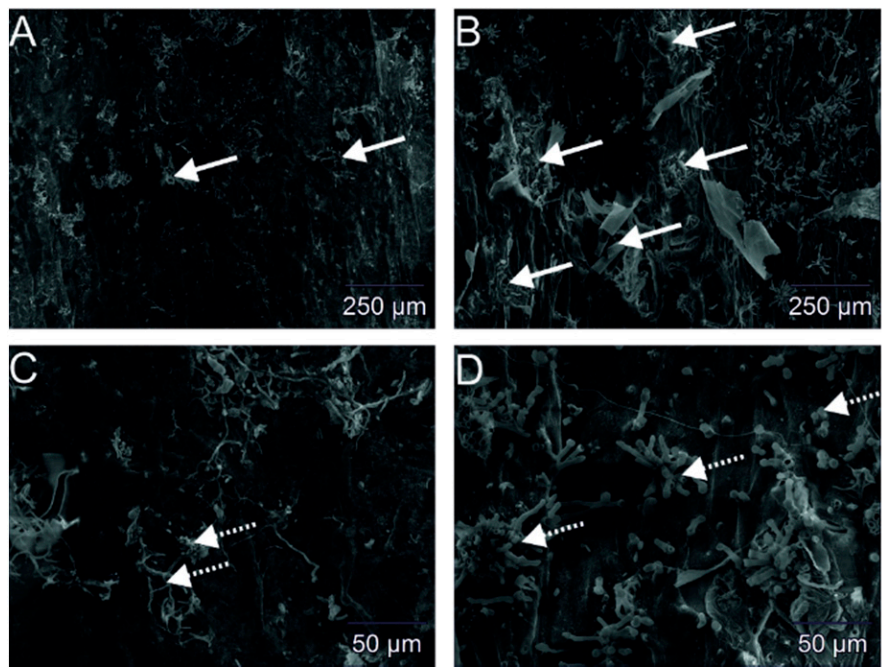

Figure 6. SEM images of the control sample and the sample disintegrated for 5 min $((\mathbf{A}, \mathbf{B})$ control sample, (C,D) disintegrated sample).

\subsection{Biogas and Methane Production}

The biogas productivity from undisintegrated rapeseed straw without pre-treatment averaged $416.4 \pm 20.5 \mathrm{NmL} / \mathrm{g}$ VS. The highest biogas production was obtained in the sample disintegrated for $5 \mathrm{~min}$, and averaged $478.0 \pm 27.5 \mathrm{NmL} / \mathrm{g}$ VS. The methane yield from undisintegrated rapeseed straw averaged $255.2 \pm 7.7 \mathrm{NmL} \mathrm{CH}_{4} / \mathrm{g} \mathrm{VS}$, while in the sample pre-treated for $5 \mathrm{~min}$ averaged $290.8 \pm 12.1 \mathrm{NmL} \mathrm{CH}_{4} / \mathrm{g}$ VS. The application of PEF pre-treatment did not affect the qualitative composition of the produced biogas and, for all of the samples, the methane content ranged from $60.7 \%$ to $61.5 \%$, on average (Figure 7 ). The productivity of methane was positively correlated with the value of the chemical oxygen demand $(R=0.63)$ and the concentration of total organic carbon $(R=0.70)$. The highest value of the methane production rate $(r)$ was observed in the disintegrated sample for $6 \mathrm{~min}$, and it was $117.06 \mathrm{NmL} / \mathrm{g}$ VS d. The highest values of the reaction rate constant were observed in the disintegrated tests for 6 and $8 \mathrm{~min}$ (Table 2).

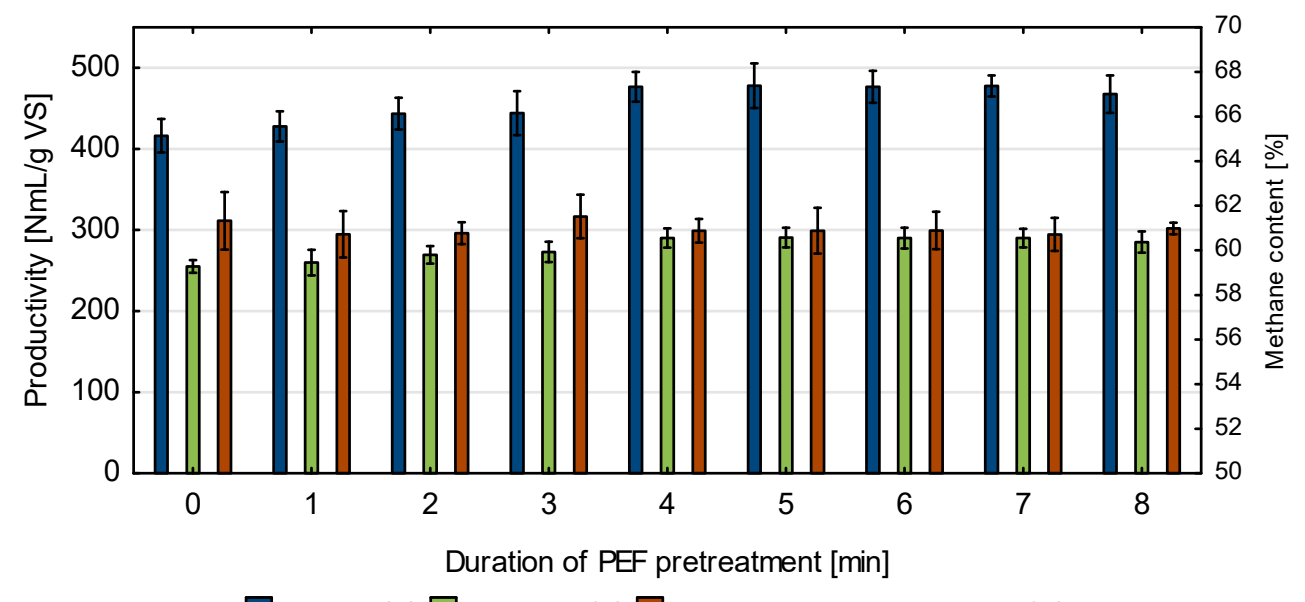

Biogas (L) $\square$ Methane (L) $\square$ Methane content in biogas (R)

Figure 7. Biogas production, methane production and methane content in biogas after PEF pre-treatment. 
Table 2. Kinetic parameters of methane production from PEF-pre-treated substrate, as determined from the first-order model.

\begin{tabular}{cccccc}
\hline $\begin{array}{c}\text { Disintegration } \\
\text { Time [min] }\end{array}$ & $\begin{array}{c}\mathbf{Q} \\
{[\mathbf{N m L / g} \text { VS] }}\end{array}$ & $\begin{array}{c}\mathbf{Q e} \\
{[\mathbf{N m 1 / g} \mathbf{~ V S}]}\end{array}$ & $\begin{array}{c}\mathbf{r} \\
{[\mathbf{N m L / g} \text { VS } / \mathbf{d}]}\end{array}$ & $\begin{array}{c}\mathbf{k} \\
{[\mathbf{1} / \mathbf{d}]}\end{array}$ & $\mathbf{R}^{\mathbf{2}}$ \\
\hline 0 & 372.63 & 369.03 & 81.36 & 0.22 & 0.99 \\
\hline 1 & 379.50 & 369.61 & 95.32 & 0.26 & 0.98 \\
\hline 2 & 393.50 & 387.95 & 78.03 & 0.20 & 0.98 \\
\hline 3 & 401.43 & 407.57 & 66.17 & 0.16 & 0.99 \\
\hline 4 & 426.60 & 423.88 & 77.01 & 0.18 & 0.98 \\
\hline 5 & 427.53 & 412.87 & 115.47 & 0.28 & 0.98 \\
\hline 6 & 420.8 & 407.17 & 117.06 & 0.29 & 0.98 \\
\hline 7 & 420.6 & 407.51 & 103.81 & 0.26 & 0.98 \\
\hline 8 & 413.5 & 400.54 & 114.37 & 0.29 & 0.98 \\
\hline
\end{tabular}

Research on the effect of the pre-treatment of a lignocellulosic substrate with PEF was conducted by Kovačić et al. [28]. In their study, they used maize and soybean straw as lignocellulosic material. They conducted the pre-treatment by generating a voltage of 200-300 V. The biogas yield from the co-fermentation of cattle manure and the disintegrated substrate was $56.22 \mathrm{~mL} / \mathrm{g}$ VS for maize straw and $402.22 \mathrm{~mL} / \mathrm{g}$ VS for soy straw. Methane production increased by $13 \%$ and $17 \%$, respectively, compared to the control sample. The highest energy gain was obtained for the electric field intensity $\mathrm{U}=0.90-1.60 \mathrm{kV} / \mathrm{cm}$, and it was $15.25 \mathrm{kWh} / \mathrm{t}$. The obtained energy gain is about four times lower than the authors presented in the discussed research. Szwarc et al. used a PEF to pre-treat maize silage in the methane fermentation process. Due to the disintegration of PEF, they achieved an increase in methane production at the level of $16 \%$, which resulted in them obtaining an energy profit of $0.235 \mathrm{Wh} / \mathrm{g}$ TS. The obtained energy gain was over four times higher than that in the presented work [27]. However, Wang et al. [45] used PEF disintegration to increase the biogas productivity from Hybrid Pennisetum. Using PEF pre-treatment $(15 \mathrm{kV} / 120 \mathrm{~Hz})$, they obtained an increase in cumulative biogas production by about $27 \%$ for an undisintegrated sample. The effect of PEF treatment on biogas productivity was also studied by Kuş̧̧u et al. [40]. In their study, they used waste activated sludge treated with $36 \mathrm{kV}$ as the substrate. Their experiment showed that the application of PEF disintegration to activated sludge resulted in increased methane productivity by $73 \%$ and biogas productivity by $70 \%$. Zou et al. [46] studied the effect of a PEF on methane production from food waste, and found that PEF pre-treatment increased methane production by $34.6 \%$. The analysis of scientific publications reported by other authors and the results of the research presented in the discussed paper confirm the possibility of using PEF to increase the production of methane in anaerobic digestion.

The obtained results allowed the energy value of the produced methane to be calculated (Table 3). The energy input $\left(\mathrm{E}_{\mathrm{in}}, \mathrm{Wh} / \mathrm{g}\right.$ TS) in the disintegration process is the real energy consumed by the high voltage power supply. $\mathrm{E}_{\text {out }}$ (Wh/g TS) was determined using the following equation:

$$
E_{\text {out }}=\Delta \mathrm{P} \times \xi
$$

where $\triangle \mathrm{P}$ is the increase in methane production after PEF disintegration and $\xi$ is the energy value of methane $9.17 \mathrm{kWh} / \mathrm{m}^{3} \mathrm{CH}_{4}$.

The energy gain $\left(\mathrm{E}_{\mathrm{T}}, \mathrm{Ws} / \mathrm{g} \mathrm{TS}\right)$ was determined from the difference between the input energy $\left(E_{\text {in }}\right)$ and the output energy $\left(E_{\text {out }}\right)$ according to the following equation:

$$
E_{T}=E_{\text {in }}-E_{\text {out }}
$$


Table 3. Energy efficiency of the PEF treatment of rapeseed straw.

\begin{tabular}{cccc}
\hline $\begin{array}{c}\text { Pre-Treatment } \\
\text { Time [min] }\end{array}$ & $\begin{array}{c}\mathbf{E}_{\text {in }} \\
\text { (Wh/g TS) }\end{array}$ & $\begin{array}{c}\mathbf{E}_{\text {out }} \\
\text { (Wh/g TS) }\end{array}$ & $\begin{array}{c}\mathbf{E}_{\mathbf{T}} \\
\text { (Wh/g TS) }\end{array}$ \\
\hline 0 & - & - & - \\
1 & 0.05 & 0.04 & -0.11 \\
2 & 0.11 & 0.12 & 0.01 \\
3 & 0.13 & 0.14 & 0.01 \\
4 & 0.22 & 0.28 & 0.06 \\
5 & 0.26 & 0.29 & 0.03 \\
6 & 0.33 & 0.30 & -0.03 \\
7 & 0.39 & 0.29 & -0.10 \\
8 & 0.44 & 0.25 & -0.18 \\
\hline
\end{tabular}

The highest energy gain was achieved for the sample pre-treated for $4 \mathrm{~min}$, and was $0.06 \mathrm{Wh} / \mathrm{g}$ TS. A further increase in the pre-treatment time did not result in an increase in the energy gain, which was related to the increasing energy input for PEF disintegration. Zieliński et al. used hydrodynamic cavitation to disintegrate Sida hermaphrodita. With the energy input of $0.28 \mathrm{Wh} / \mathrm{g}$ TS, the increase in methane production resulted in an energy gain of $0.17 \mathrm{Wh} / \mathrm{g}$ TS [34].

\section{Conclusions}

Considering the wide availability of lignocellulosic biomass, the use of this feedstock for the production of an energy carrier in methane fermentation is a good step toward meeting the world's energy demand. Due to its composition, lignocellulosic biomass is characterized by high resistance to enzymatic decomposition, which necessitates pre-treatment to increase the biogas potential. The presented studies indicate that the application of PEF treatment can increase the productivity of biogas obtained from rapeseed straw.

The best result was achieved with a 5-min PEF pre-treatment, in which the methane production coefficient reached $290.8 \pm 12.1 \mathrm{NmL} \mathrm{CH}_{4} / \mathrm{g} \mathrm{VS}$, which was about $14 \%$ higher than the control sample. The biogas productivity for this sample was $478.0 \pm 27.5 \mathrm{NmL} / \mathrm{g} \mathrm{VS}$, a value approximately $15 \%$ higher than the control sample. Due to the energy gain, the sample disintegrated for 4 min was the most effective, and was $0.06 \mathrm{Wh} / \mathrm{g}$ TS.

SEM observation showed that, in the disintegrated sample, the extent of damage to the plant tissue was more severe than in the control sample. The greatest increase in chemical oxygen demand was obtained in the disintegrated sample for $7 \mathrm{~min}$. The value increased from $4146 \pm 75 \mathrm{mg} / \mathrm{L}$ to $4920 \pm 60 \mathrm{mg} / \mathrm{L}$.

Author Contributions: Conceptualization, D.S.; funding acquisition, D.S.; investigation, D.S. and K.G.; methodology, D.S. and K.G.; supervision, D.S.; visualization, D.S. and K.G.; writing—original draft, D.S.; writing-review and editing, D.S. All authors have read and agreed to the published version of the manuscript.

Funding: The research was funded by the National Centre for Research and Development as part of the LIDER IX programme. The project was entitled "Development a lignocellulose biomass disintegration technology using a pulsed electric field" LIDER/8/0026/L-9/17/NCBR/2018. The subsidy amount was PLN 1,166,250.00. The APC was funded by the National Centre for Research and Development.

Institutional Review Board Statement: Not applicable.

Informed Consent Statement: Not applicable.

Data Availability Statement: Data sharing not applicable.

Conflicts of Interest: The authors declare no conflict of interest. 


\section{References}

1. Li, P.; Sakuragi, K.; Makino, H. Extraction Techniques in Sustainable Biofuel Production: A Concise Review. Fuel Process. Technol. 2019, 193, 295-303. [CrossRef]

2. Alalwan, H.A.; Alminshid, A.H.; Aljaafari, H.A.S. Promising Evolution of Biofuel Generations. Subject Review. Renew. Energy Focus 2019, 28, 127-139. [CrossRef]

3. Scaramuzzino, C.; Garegnani, G.; Zambelli, P. Integrated Approach for the Identification of Spatial Patterns Related to Renewable Energy Potential in European Territories. Renew. Sustain. Energy Rev. 2019, 101, 1-13. [CrossRef]

4. Olatunji, K.O.; Ahmed, N.A.; Ogunkunle, O. Optimization of Biogas Yield from Lignocellulosic Materials with Different Pretreatment Methods: A Review. Biotechnol. Biofuels 2021, 14, 1-34. [CrossRef]

5. Chintagunta, A.D.; Zuccaro, G.; Kumar, M.; Kumar, S.P.J.; Garlapati, V.K.; Postemsky, P.D.; Kumar, N.S.S.; Chandel, A.K.; Simal-Gandara, J. Biodiesel Production from Lignocellulosic Biomass Using Oleaginous Microbes: Prospects for Integrated Biofuel Production. Front. Microbiol. 2021, 12, 2080. [CrossRef] [PubMed]

6. Yadav, M.; Paritosh, K.; Vivekanand, V. Lignocellulose to Bio-Hydrogen: An Overview on Recent Developments. Int. J. Hydrogen Energy 2020, 45, 18195-18210. [CrossRef]

7. Tuong, T.; Tran, A.; Kim, T.; Le, P.; Mai, T.P.; Nguyen, D.Q. Bioethanol Production from Lignocellulosic Biomass. Xiandai Huagong/Mod. Chem. Ind. 2019, 31, 40-44.

8. Liu, X.; Xu, W.; Mao, L.; Zhang, C.; Yan, P.; Xu, Z.; Zhang, Z.C. Lignocellulosic Ethanol Production by Starch-Base Industrial Yeast under PEG Detoxification. Sci. Rep. 2016, 6, 1-11. [CrossRef] [PubMed]

9. $\mathrm{Hu}, \mathrm{X}$; Gholizadeh, M. Biomass Pyrolysis: A Review of the Process Development and Challenges from Initial Researches up to the Commercialisation Stage. J. Energy Chem. 2019, 39, 109-143. [CrossRef]

10. Gollakota, A.R.K.; Kishore, N.; Gu, S. A Review on Hydrothermal Liquefaction of Biomass. Renew. Sustain. Energy Rev. 2018, 81, 1378-1392. [CrossRef]

11. Bekchanov, M.; Mondal, M.A.H.; de Alwis, A.; Mirzabaev, A. Why Adoption Is Slow despite Promising Potential of Biogas Technology for Improving Energy Security and Mitigating Climate Change in Sri Lanka? Renew. Sustain. Energy Rev. 2019, 105, 378-390. [CrossRef]

12. Baskar, G.; Renganathan, S.; Zakaria, Z.A. Biofuels and Bioenergy: Opportunities and Challenges, 1st ed.; Elsevier: Amsterdam, The Netherlands, 2022.

13. Kumar, P.; Kumar, V.; Singh, J.; Kumar, P. Electrokinetic Assisted Anaerobic Digestion of Spent Mushroom Substrate Supplemented with Sugar Mill Wastewater for Enhanced Biogas Production. Renew. Energy 2021, 179, 418-426. [CrossRef]

14. Mirmohamadsadeghi, S.; Karimi, K.; Azarbaijani, R.; Parsa Yeganeh, L.; Angelidaki, I.; Nizami, A.S.; Bhat, R.; Dashora, K.; Vijay, V.K.; Aghbashlo, M.; et al. Pretreatment of Lignocelluloses for Enhanced Biogas Production: A Review on Influencing Mechanisms and the Importance of Microbial Diversity. Renew. Sustain. Energy Rev. 2021, 135, 110173. [CrossRef]

15. Igliński, B.; Buczkowski, R. Potencjał Techniczny i Możliwości Wykorzystania Biogazu Utylizacyjnego Na Przykładzie Województwa Warmińsko-Mazurskiego. Rynek Energii 2017, 4, 56-62.

16. Wu, D.; Wei, Z.; Zhao, Y.; Zhao, X.; Mohamed, T.A.; Zhu, L.; Wu, J.; Meng, Q.; Yao, C.; Zhao, R. Improved Lignocellulose Degradation Efficiency Based on Fenton Pretreatment during Rice Straw Composting. Bioresour. Technol. 2019, $294,122132$. [CrossRef]

17. Kamaraj, M.; Ramachandran, K.K.; Aravind, J. Biohydrogen Production from Waste Materials: Benefits and Challenges. Int. J. Environ. Sci. Technol. 2020, 17, 559-576. [CrossRef]

18. Enshaeieh, M.; Abdoli, A.; Madani, M.; Bayat, M. Recycling of Lignocellulosic Waste Materials to Produce High-Value Products: Single Cell Oil and Xylitol. Int. J. Environ. Sci. Technol. 2015, 12, 837-846. [CrossRef]

19. Brahim, M.; Checa Fernandez, B.L.; Regnier, O.; Boussetta, N.; Grimi, N.; Sarazin, C.; Husson, E.; Vorobiev, E.; Brosse, N. Impact of Ultrasounds and High Voltage Electrical Discharges on Physico-Chemical Properties of Rapeseed Straw's Lignin and Pulps. Bioresour. Technol. 2017, 237, 11-19. [CrossRef] [PubMed]

20. López-Linares, J.C.; Ballesteros, I.; Tourán, J.; Cara, C.; Castro, E.; Ballesteros, M.; Romero, I. Optimization of Uncatalyzed Steam Explosion Pretreatment of Rapeseed Straw for Biofuel Production. Bioresour. Technol. 2015, 190, 97-105. [CrossRef]

21. Talebnia, F.; Mighani, M.; Rahimnejad, M.; Angelidaki, I. Ethanol Production from Steam Exploded Rapeseed Straw and the Process Simulation Using Artificial Neural Networks. Biotechnol. Bioprocess Eng. 2015, 20, 139-147. [CrossRef]

22. Díaz, M.J.; Cara, C.; Ruiz, E.; Romero, I.; Moya, M.; Castro, E. Hydrothermal Pre-Treatment of Rapeseed Straw. Bioresour. Technol. 2010, 101, 2428-2435. [CrossRef]

23. Guo, J.; Huang, K.; Cao, R.; Zhang, J.; Xu, Y. Aliphatic Extractive Effects on Acetic Acid Catalysis of Typical Agricultural Residues to Xylo-Oligosaccharide and Enzymatic Hydrolyzability of Cellulose. Biotechnol. Biofuels 2021, 14, 97. [CrossRef]

24. Ahmed, B.; Aboudi, K.; Tyagi, V.K.; Álvarez-Gallego, C.J.; Fernández-Güelfo, L.A.; Romero-García, L.I.; Kazmi, A.A. Improvement of Anaerobic Digestion of Lignocellulosic Biomass by Hydrothermal Pretreatment. Appl. Sci. 2019, 9, 3853. [CrossRef]

25. Karuppiah, T.; Azariah, V.E. Biomass Pretreatment for Enhancement of Biogas Production. Anaerobic Digestion 2019, $150,111509$.

26. Li, M.; Pu, Y.; Ragauskas, A.J. Current Understanding of the Correlation of Lignin Structure with Biomass Recalcitrance. Front. Chem. 2016, 4, 45. [CrossRef]

27. Szwarc, D.; Szwarc, K. Use of a Pulsed Electric Field to Improve the Biogas Potential of Maize Silage. Energies 2020, $14,119$. [CrossRef] 
28. Kovačić, Đ.; Kralik, D.; Rupčić, S.; Jovičić, D.; Spajić, R.; Tišma, M. Electroporation of Harvest Residues for Enhanced Biogas Production in Anaerobic Co-Digestion with Dairy Cow Manure. Bioresour. Technol. 2019, 274, 215-224. [CrossRef] [PubMed]

29. Kucharska, K.; Rybarczyk, P.; Hołowacz, I.; Łukajtis, R.; Glinka, M.; Kamiński, M. Pretreatment of Lignocellulosic Materials as Substrates for Fermentation Processes. Molecules 2018, 23, 2937. [CrossRef] [PubMed]

30. Arora, A.; Nandal, P.; Singh, J.; Verma, M.L. Nanobiotechnological Advancements in Lignocellulosic Biomass Pretreatment. Mater. Sci. Energy Technol. 2020, 3, 308-318. [CrossRef]

31. Dahunsi, S.O. Mechanical Pretreatment of Lignocelluloses for Enhanced Biogas Production: Methane Yield Prediction from Biomass Structural Components. Bioresour. Technol. 2019, 280, 18-26. [CrossRef]

32. Kong, X.; Du, J.; Ye, X.; Xi, Y.; Jin, H.; Zhang, M.; Guo, D. Enhanced Methane Production from Wheat Straw with the Assistance of Lignocellulolytic Microbial Consortium TC-5. Bioresour. Technol. 2018, 263, 33-39. [CrossRef] [PubMed]

33. Wyman, V.; Henríquez, J.; Palma, C.; Carvajal, A. Lignocellulosic Waste Valorisation Strategy through Enzyme and Biogas Production. Bioresour. Technol. 2018, 247, 402-411. [CrossRef] [PubMed]

34. Zielinski, M.; Rusanowska, P.; Krzywik, A.; Dudek, M.; Nowicka, A.; Ebowski, M.D. Application of Hydrodynamic Cavitation for Improving Methane Fermentation of Sida Hermaphrodita Silage. Energies 2019, 12, 526. [CrossRef]

35. Liu, Y.; Nie, Y.; Lu, X.; Zhang, X.; He, H.; Pan, F.; Zhou, L.; Liu, X.; Ji, X.; Zhang, S. Cascade Utilization of Lignocellulosic Biomass to High-Value Products. Green Chem. 2019, 21, 3499-3535. [CrossRef]

36. Safavi, S.M.; Unnthorsson, R. Enhanced Methane Production from Pig Slurry with Pulsed Electric Field Pre-Treatment. Environ. Technol. 2018, 39, 479-489. [CrossRef]

37. Golberg, A.; Sack, M.; Teissie, J.; Pataro, G.; Pliquett, U.; Saulis, G.; Stefan, T.; Miklavcic, D.; Vorobiev, E.; Frey, W. Energy-Efficient Biomass Processing with Pulsed Electric Fields for Bioeconomy and Sustainable Development. Biotechnol. Biofuels 2016, 9, 1-22. [CrossRef]

38. Van Soest, P.J.; Robertson, J.B.; Lewis, B.A. Methods for Dietary Fiber, Neutral Detergent Fiber, and Nonstarch Polysaccharides in Relation to Animal Nutrition. J. Dairy Sci. 1991, 74, 3583-3597. [CrossRef]

39. Cydzik-Kwiatkowska, A.; Rusanowska, P.; Głowacka, K. Operation Mode and External Carbon Dose as Determining Factors in Elemental Composition and Morphology of Aerobic Granules. Arch. Environ. Prot. 2016, 42, 74-79. [CrossRef]

40. Kuşçu, Ö.S.; Çömlekçi, S.; Çört, N. Disintegration of Sewage Sludge Using Pulsed Electrical Field Technique: PEF Optimization, Simulation, and Anaerobic Digestion. Environ. Technol. 2021, 1-16. [CrossRef]

41. Deng, Y.D.; Gao, Y.; Men, Y.K.; Du, B.X.; Wang, Y.N.; Liu, C.H. Effect of DC Corona on Performance of Pulsed Electric Field Pretreatment on Waste Activated Sludge. In Proceedings of the 2016 IEEE Conference on Electrical Insulation and Dielectric Phenomena (CEIDP), Toronto, ON, Canada, 16-19 October 2016; pp. 747-750.

42. El Achkar, J.H.; Lendormi, T.; Salameh, D.; Louka, N.; Maroun, R.G.; Lanoisellé, J.L.; Hobaika, Z. Influence of Pretreatment Conditions on Lignocellulosic Fractions and Methane Production from Grape Pomace. Bioresour. Technol. 2018, 247, 881-889. [CrossRef]

43. Kim, Y.N.; Kwon, H.J.; Lee, D.U. Effects of Pulsed Electric Field (PEF) Treatment on Physicochemical Properties of Panax Ginseng. Innov. Food Sci. Emerg. Technol. 2019, 58, 102232. [CrossRef]

44. Liu, Z.; Esveld, E.; Vincken, J.P.; Bruins, M.E. Pulsed Electric Field as an Alternative Pre-Treatment for Drying to Enhance Polyphenol Extraction from Fresh Tea Leaves. Food Bioprocess Technol. 2019, 12, 183-192. [CrossRef] [PubMed]

45. Wang, B.; Chen, T.; Qin, X.; Wu, Q.; Zhao, Y.; Bai, S.; Peng, W.; Feng, B. Effect of High-Voltage Pulsed Electric Field (HPEF) Pretreatment on Biogas Production Rates of Hybrid Pennisetum by Anaerobic Fermentation. Nat. Gas Ind. B 2018, 5, 48-53. [CrossRef]

46. Zou, L.; Ma, C.; Liu, J.; Li, M.; Ye, M.; Qian, G. Pretreatment of Food Waste with High Voltage Pulse Discharge towards Methane Production Enhancement. Bioresour. Technol. 2016, 222, 82-88. [CrossRef] [PubMed] 